Current studies indicate that hunting-gathering groups may get all of the food they need without working too hard. Early agriculture suffered from the vicissitudes of the weather and it was not until about $5000 \mathrm{BC}$ that the use of irrigation, a truly revolutionary change, made it possible to grow pure stands of cereal grasses where none had grown before. The domestication of animals may have been primarily a device for the live storage of surplus foodstuffs.

Smith, an Egyptologist, describes in detail some of the notable portrayals of animals in sculpture, relief, and painting in dynastic Egypt. Especially intriguing are the illustrations showing the forcible feeding of cranes and of an animal identified as a hyena. Recd, in a thoughtful article, suggests that the bovids might have been preadapted to domestication because of their ability to survive on a diet high in cellulose and low in protein and to convert otherwise useless materials into carbohydrates, proteins, and fats by way of milk and flesh. and other valuable commodities, hides, hair, and wool and, in time, dung for fuel and for fertilizer.

From his studies on the history and ethnography of three West Indian starches-manioc, arrowroot, and zamia-Sturtevant concludes that historical documents, when available, may be more reliable than modern ethnographic data in interpreting archaeological evidence. Writing on the origin, variability, and spread of the groundnut, Krapovickas concludes that the cultivated form probably originated in Bolivia at the base or in the foothills of the Andes. It reached the Peruvian coast at an early date and after tho discovery of America spread rapidly to various parts of the Old World.

In a short but well documented and illustrated article, Drower discusses the domestication of the horse which seems to have begun not much earlier than $2000 \mathrm{BC}$. The first tamers may have been nomadic herdsmen to whom rapid mobility would have given many advantages. By $1000 \mathrm{BC}$ newer and larger breeds of horses were making their appearance and superior harness had evolved. Examining the evidence from skeletons and ancient faeces, Brothwell states that the latter had begun to give precise information on the wide range of foodstuffs consumed by individuals of different cultures and concludes that the breadth of potential information in the study of coprolites is enormous.

To one who has participated in the interdisciplinary research on the evolution of agriculture in the New World, it is somewhat disappointing to see so little attention given to the subject in this seminar. The contributions of MacNeish and his associates are mentioned only in passing, although they represent a notable example of the collaboration that Grimes prescribes in his part of the introduction. Another disappointment in reading this work is that the seminar, whose proceedings it reports and which was held in 1968, took no cognizance whatever of the fact that 1968 was the centennial of the publication of Darwin's famous The Variation of Animals and Plants under Domestication. The present generation seems sometimes unaware of its debt to the illustrious past.

Paul C. Mangelsdorf

\section{ORIGINS OF TODAY'S CUISINE}

\section{Food in Antiquity}

By Don and Patricia. Brothwell. (Ancient Peoples and Places.) Pp. 248. (67 plates.) (Thames and Hudson: London, June 1969.) 42s.

Foon is an agreeable subject to us all, and in this agreeable book Dr and Mrs Brothwell remind us that our ancestors, cspecially the Romans, were more adventurous and more ingenious in its preparation than ourselves. Fig. 16, for instance, illustrates a spccial container with holes and internal ridges, used by the Romans for fattening dormice.
Of course much has already been written on the subject of food in classical times, using historical sources. For instance, Jacques André in his I a Cuisine et l'Alimentation a Rome gives a vivid picture of Roman diet, using these sources, on which the Brothwells also draw.

In recent years the archaeologist has rightly come to regard the food quest as the primo activity of most human societies, and a rapidly increasing body of information on early subsistence is available from the study of exeavated plant and animal remains, of coprolites (preserved human faeces), and the examination of human bones. The Brothwells have courageously attompted a summary of this colossal field, from prehistoric times to the classical world, using both the preserved written records and the findings of the archacologist. In the space of a short text, only an introduction to the subject is possible. But they have made it a lively, up to date and well illustrated one, with a good bibliography.

The bulk of the text is taken up with a systematic survey of the different kinds of food resource (vertebrates, invertebrates, sugars, fungi, cereal crops, and the like). The sections dealing with molluses and honey are particularly good, as is the discussion of fungi. But it is impossible to say anything that is new about wheat, for instance, in the space of one and a half pages, or about rice, or about sheep and goats within two pages. Consequently, there is little for the specialist in this principal and encyclopacdic section.

In their introduction, however, and in the concluding chapter, "Diet and Disease", the authors impose their own perspective on this complicated picture, with pertinent comments on infant feeding in antiquity and on vitamin. deficiencies. Several books remain to be written here, which the Brothwells would be well qualified to produce.

Meanwhile they have produced an agreeable introduction to this vast field, with well selected illustrations, which can be read with enjoyment by all interested in man's past or in the early origins of today's cuisine.

Colin Renfrew

\section{Obituaries}

\section{Academician V. A. Kargin}

Valentin Alekseevich Kargin, who died on October 21, aged sixty-three, was a colloid and polymer chemist with a high reputation all over the world. He was born on January 23, 1907, in Dnepropetrovsk, and began his active scientific career at the age of fifteen, publishing several papers on analytical chemistry and electrochemistry by the time he was twenty. From then until he was about thirty Kargin was concerned chiefly with the physical chemistry of colloidal systems. It is now said to be difficult to imagine any aspect of the physical chemistry of high molecular compounds with which he was not associated.

Kargin began work as a laboratory assistant in the L. P. Karpov Physical Chemistry Institute in Moscow in 1924, and was to stay there for forty-five years. Early in his career he also studied at Moscow State University, finishing in 1930. Six years later he was given his doctorate for work on colloid chemistry, without the formality of a thesis. Other awards and distinctions for his scientific and social contributions followed.

In 1956 he founded the Department of High Molecular Compounds at Moseow State University, the first of its kind in the Soviet Union. He directed this department until the end of his life, as well as running the colloidal chemistry laboratory of the Karpov Institute, which he took over in 1937. During part of his career Kargin also directed polymer research at the A. V. Topchiev Institute of Petrochemical Synthesis. 
He was always interested in the training of young scientists, and his work created a branch of Soviet chemistry that produced many young polymer scientists. He was one of the organizers, and editor in chief, of the Soviet journal V'ysokomolekulyarnȳe (high molecular compounds). In Britain his name is familiar in, for example, the documentation of rubber and plasties. His classic work, Short Sketches in the Physical Chemistry of Polymers, written in collaboration with Slonimskii, and the Kargin balance for thermomechanical testing of polymers, are often roferred to. His work on the thermodynamies of solutions of high molecular compounds and on the structure of polymers made a fundamental contribution to the foundation of modern theories concerned with the processing of plastics, rubbers and synthetic fibres.

Kargin was greatly respected by his own people and by scientists all over the world. He was an international figure, unlike some of his scientist colleagues who rarely left the Soviet Union. For his outstanding scientific achievements he was made a Hero of Socialist Labour, awarded the Order of Lenin three times, the Order of the Red Banner twice and several medals. He also received the Lenin prizo and three State Prizes. He became a corresponding member of the USSR Academy of Sciences in 1946 and an Academician in 1953.

\section{Correspondence}

\section{Research Associations and Higher Education}

SIR,-It is clear that the future of higher education in this country is still uncertain. Even so short a time after the Robbins Report another such study has been called for in the recent Parliamentary Select Committee Report on university reform. This report followed an independent attack on the government's seeming indifference to the well-being of polytechnic development (Nature, 224, 1; 1969).

The trouble with the so-called binary system is that polytechnic training can hardly be regarded as providing a parallel route comparable with that of the university. I would suggest that the status of the polytechnic could be dramatically changed simply by linking the polytechnic movernent with that of the industrial research association (RA). Research associations are largely financed by levies and subscriptions from member firms but receive public grants pro rata through the Ministry of Technology, although initially it was ordained that they would become self-supporting after a reasonable period. The ministry should now say that this time has arrived and it should divert the grants in a phased operation to the polytechnies, to be used either in developing postgraduate work or in enlarging their sphere of activities in ways of their own choice. The industrial federation would be encouraged to transfer its present RA activities either to the nearest polytechnic or to polytechnics en bloc, sharing equipment, buildings and staff so that in effect the RA would become the postgraduate faculty of the polytechnic. The union of the staffs would bring about the oft-claimed advantage of research and teaching being shared.

Where geographically a total transfer would be difficult, firms at present contributing to their RA could make a separate but similar arrangement on a regional basis.

Independent of degree work, special short courses involving expertise at varying levels of the industrial scene would become common and because the RAs do not recognize academic terms their influence would break down this hangover from the university past and ensure a more efficient use of buildings and equipment. This would not mean, of course, interference with the freedom of the industrial federation to continue its present RA; all it would be asked to do would be to pay for it.
I also suggest that the process of setting up of industrial advisory contres in the universities should be halted and the scheme centred on the polytechnics. This would avoid the present waste of effort whereby the Ministry of Technology sets up its industrial liaison officers in universities and polytechnics, although they offer the same service as has already been offered for years by the RAs, often in the same town.

Difficulties of course there would be, but they would not be formidable. The proposal would also silence those critics who suggest it is time that the cost-effectiveness of the RA movement was looked at.

$$
\begin{aligned}
& \text { Yours faithfully, } \\
& \text { H. G. HoweLL }
\end{aligned}
$$

10 Pelham Crescent,

The Park,

Nottingham.

\section{Enzymes at Houston}

Sir,- In the note "Enzymes at Houston" (Nature, 223, $336 ; 1969$ ), you wrote that "the mood of practising doctors in Britain seems to be running somewhat against enzyme assays just now, at any rate for purposes such as the diagnosis of myocardial infarction". This is not correct. Assays of enzymes, released from damaged myocardial muscle, are increasingly used in diagnosis of infarction. A sharp rise of the serum glutamic-oxacetic transaminase (SGOT), maximal at about $24 \mathrm{~h}$ after infarction and lasting for only a day or so, is of great value in the detection of myocardial cell damage; this estimation is particularly useful if the electrocardiogram is already abnormal from previous myocardial disorders. A rise of lactic dehydrogenase (TDH) at 4-7 days after infarction is of less value. In other fields of medicine, assays of serum glutamic-pyruvic transaminase (SGP'I) provide valuable evidence of liver cell damage, and serum creatinine phosphokinase (CPK) measurements are useful in muscle disorders associated with rapid cell degeneration. The use of other enzyme assays is being explored.

\section{Yours faithfully,}

D. N. Phear

Queen Elizabeth Hospital,

Welwyn Garden City,

Hertfordshire.

\section{No Peace for the Wicked}

SrR,-Many biologists must disagree with the overoptimistic attitude of the editorial "No peace for the wicked" (Nature, 224, 629; 1969). In particular, it is difficult to understand how anyone with a knowledge of the figures can say that population increase is unlikely to be a social disaster. At present the world population is too large for the amount of food available, in spite of continued agricultural advances. How much longer will our luck last? Little thought is given to the danger of disease, perhaps a new variant of influenza or something similar, sweeping through these large, under-fed, populations of Homo sapiens with all the subsequent social upheaval caused by very high death rates.

Isn't it time that biologists and others thought a little more about the advantages of stable populations? After all, species that show large fluctuations in numbers, with all the "misery" of population "crashes", are in the minority.

A stable population could have enormous economic advantages and Britain could set an example to the rest of the world. Man not only needs food and shelter, but also enough room to be able to own his home, for we appear to be a territorial species. We all desire a high degree of education for our children, yet the present system is in chaos for lack of funds. Haven't we perhaps 